\title{
RFID and Supply Chain Management for Manufacturing Digital Enterprise
}

\author{
Gordana Matičević ${ }^{1}$, Mirjana Čičak ${ }^{2}$ and Tadija Lovrić ${ }^{3}$ \\ 1,2J.J. Strossmayer University of Osijek, \\ Mechanical Engineering Faculty in Slavonski Brod \\ Inin plc., Slavonski Brod \\ Croatia
}

\section{Introduction}

In today's complex and dynamic business environment manufacturing enterprises have to change their business processes to ensure customization of products, flexibility and responsiveness to the customer's and business partner's requirements in order to improve their competitiveness. Globalization of market, growth variants of product, decrease of product life cycles, and increasingly sophisticated customer requirements stress the need for integration with supply chain partners. It becomes necessary to reduce production volumes and make products that satisfy customer specific needs. This can only be achieved by implementing technologies such as enterprise resource planning systems (ERP) and radio frequency identification (RFID) technology to improve operational efficiencies and establish better relationship with their business partners. Enterprises have to integrate information and communications technologies to improve internal processes (within the enterprise) and external processes (with business partners in the supply chain). ERP implementation within the enterprise provides managers with information and enables them to make the effective decisions. Information about events in the supply chain, internal as well as external, must be timely, accurate, complete, adequate and reliable. It is necessary to share real-time information and coordinate all activities of business processes. Lack of accurate real-time information about production status from shopfloor (e.g. Work-In-Process and inventory status) may adversely affect performance, especially of just-in-time manufacturing (JIT) and supply chain planning. Using Radio Frequency Identification (RFID) technology physical objects (raw materials, parts, products, equipment, shipments and personnel) could be integrated by assigned identity (which is typically a number unique to each object) with the Enterprise Resource Planning (ERP) system in the real time and provide information visibility and information sharing in a manufacturing digital enterprise.

Radio frequency identification technology is a remarkable business tool for many aspects of business including Supply Chain Management (SCM). RFID is a growing technology that enables close cooperation of the supply chain partners by real-time information visibility.

Manufacturing enterprises in developing countries like Croatia cope with the quality problems regarding production logistic which is necessary in order to increase capabilities for competitive response to market or supply chain partner's demands. Croatia is making huge efforts to access the European Union (EU) and cannot isolate itself from increasing 
globalisation and digitalisation in the environment. EU Initiative i2010 promotes an open and competitive digital economy and emphasises Information and Communication Technologies (ICT) as a driver of inclusion and quality of life. Also, primary goals of a new EU strategy - the Digital Agenda for Europe 2010-2020 are overcoming the crisis, preparing of the EU economy for the challenges of the next period and achieving a prosperous digital economy by 2020. Since Croatia is preparing itself for EU membership, goals of Programme e-Croatia 2007 mostly correspond with Initiative i2010 goals and Digital Agenda. Economy modernisation and increased productivity are crucial to future growth prospects for Croatia. Enterprises tend to achieve complementarities of inter-functional and inter-organizational integration and coordination throughout supply chain. Because of the need for more effective and efficient supply chain management, internal as well as external, in this chapter we propose a conceptual framework for integration of Radio Frequency Identification (RFID) with Enterprise Resource Planning (ERP) system in manufacturing digital enterprise. The objective of our conceptual framework is to enable real-time status information about material, products, workers and other resources needed for management decisions, in the context of hierarchical planning and scheduling according to just-in-time principles. This way we expect achieving a timely and efficient access to information and fast response to requests, in order to achieve coordination of production, procurement and marketing. The system should enhance the visibility of information and material flows in the internal as well as external supply chain, thus a more effective and efficient business processes and real-time information for management support in digital enterprise should be attained. Rapid development of information and communication technology, such as the Radio Frequency Identification (RFID), is one of the important factors for improving the competitive advantages. But, the advantages of RFID system will not be exploited if they are applied only within the enterprise, without the use of RFID system by other supply chain partners (Lin, 2009).

In this chapter authors give a comprehensive overview of RFID technology: an introduction to the RFID technology, principles of RFID and current status of the application of RFID technologies in EU and Croatia with emphasis on application of RFID, especially for supply chain management, both internal and external. The chapter will provide useful information regarding the importance of technology in achieving and sustaining a competitive advantage in today's dynamic market.

\section{Problem description}

Information inaccuracy can adversely affect supply chain performances by lack of inventories, delay in delivery times, lost sales and decreased customer satisfaction. Realtime information is essential for making efficient and good decisions. Without real-time information about specific requirement or any kind of disturbances in supply chain (machine breakdown, human errors, rush orders, problems supplying required raw material or components, etc.) erroneous managerial decisions occur. Variation in production affects downstream members of internal supply chain (e.g. supply of parts to assembly line) and their planning and scheduling, and consequently could affect partners in supply chain. Coordination, integration and particularly sharing information in real-time about resource constraints, plans and schedules with other supply chain members are very important (Yin $\&$ Khoo, 2007). The status and related information about each component in production must be monitored individually through its internal and external supply chain. The most of Croatian enterprises still use labour-intensive methods (enter data manually and using bar- 
code systems) for products-related data acquisition. Due to limitations in data acquisition and data interchange between shop floor and ERP system, data is often unreliable and incomplete and needed production status information is unavailable at the right place and at the right time to make effective decisions. As a consequence of problems in existing methods of identifying and tracking parts and products, mislay of parts and products, schedule delay and late deliveries occur and costs increase. To solve this production management problem, automated data acquisition is necessary in order to enable the flow of required information to everyone who needs them through integrated enterprise system and supply chain. There is a need for an integral enterprise integration, and also external integration of enterprise with supply chain partners.

At today's level of ERP systems, the integration of data is organized in data warehouses and new models and methods for data analysis and calculation of expected business trends are the most significant in order to increase the effectiveness of ERP systems. Also, it is very important to increase the speed of data transfer between the systems and to create conditions for the development of digital enterprise. The concept of digital enterprise is related to an enterprise in which the communication (exchange of information, messages, instructions, technical and technological documentation) between workers, workers and machines, and also machines to machines is performed digitally. RFID technology is one of the technologies that enable automatic object-to-object communication which is unique to digital manufacturing enterprises as mentioned previously.

\section{Literature review}

The most of available literature about RFID technology is focused to application of RFID technology for warehouse management and supply chain management (Attaran, 2007; Poon et al., 2009). Application of RFID technology in supply chain management has become fast evolving area of development and interests of academics and practitioners in recent years. For data collection about RFID authors used literature about technology and also experience of the use of RFID technology in industry environment. Comprehensive review of available RFID and SCM-specific academic literature: papers from journals, conference papers, book chapters, dissertations etc. was conducted in order to obtain a general overview of RFID technology and supply chain management.

\subsection{RFID and supply chain management}

Information technology has been recognized as an issue of vital importance for RFID system to support supply chain management (SCM) (Angeles, 2009). Zhou (2009) presents different perspective by modeling item-level information visibility in general, unlike most of case study papers about RFID. Various enterprises use RFID to achieve organizational change and manage growth in today's competitive environment (Chao, Yang \& Jen, 2007). RFID technology is essential in order to support real-time decisions in supply chain management (Chatziantoniou, Pramatari \& Sotiropoulos, 2011). Tajima (2007) argues that, „RFID is expected to produce many benefits in supply chain management" and unlike other authors he provides insights into competitiveness as the value of RFID. Comprehensive overview of impact RFID on supply chain management is given by Sarac, Absi \& DauzerePeres (2010). Their survey shows that RFID technology might improve traceability and visibility of products and processes, increase efficiency and speed of processes, improve information accuracy and might decrease inventory losses. Although the authors presented 
several advantages of RFID technologies in supply chains, they also emphasise limitations of previous research and need for more realistic analysis of supply chains.

The most applications of RFID in supply chain management currently take advantage of the technology with the objective to accelerate processes and reduce costs, but the real RFID features are found in capturing new types of information in real-time and supporting decisions (Chatziantoniou, Pramatari \& Sotiropoulos, 2011). The authors consider the need of using RFID technology to improve tactical real-time decisions in supply chain management.

For implementing RFID, enterprises need to address issues of technology development, costs and international standards and rules. Sarac, Absi \& Dauzere-Peres (2008) in their study have taken in consideration that there are different RFID systems with different costs and potential profits. The results of their analysis indicate that RFID technologies can improve the supply chain performance at different ratios. Also, the economical impacts depend on the cost of the chosen technology, the tagging level, the price of the products, the income gained using the new technology, etc. There is a novel approach to analyze trade-off potential benefits with installation costs of RFID systems in terms of implementation strategies that determine an optimal location of RFID within a supply chain network (Chang, Klabjan \& Vossen, 2010). Results of that analyze clarified the value of increased visibility, which enables the early detection of losses and an increased ability to determine exactly location where the items are lost. Thus, application of RFID technology can considerably increase the efficiency of supply chain. RFID technology could also improve information flow and supply chain control and management in construction project (Wang, Lin \& Lin, 2007). Product tracking problem for the large-scale supply chain is addressed by J.M. Ko et al. (2011), the authors have designed product tracking system that can collaborate with the EPC (Electronic Product Code) Network. According to Dias et al. (2009) few enterprises realized flexibility and increased competitiveness over the recent decade through implementation of 'lean' and 'just-in-time' principle. Unlike many analytical studies, investigate the benefits of RFID technology under more realistic setting is presented by Sari (2010); results from the simulation model show that RFID technology integration within a supply chain enables significantly greater benefits when the level of collaboration between the participants is more intensive.

At today's global market enterprises compete between each other no more, the competition has been moved between supply chains instead (D. Zhang, 2006). Integration and coordination of supply chain and ERP system is very important in various industries (Tarn, Yen \& Beaumont, 2002; Koh, Saad \& Arunachalam, 2006). Zhou (2009) analysed RFID benefits from different perspective by modeling item-level information visibility in general and his results showed that the benefit due to item-level visibility increases with the scale of the information system. Chao, Yang \& Jen (2007) applied bibliometric methods and historical reviews from 1991 through 2005 in their research that indicates increasing usage of RFID in various enterprises to improve efficiency of operations.

Study presented by E.Y. Kim et al. (2008) emphasizes importance of RFID benefits of supply chain management to business performance. Overview of the recent developments in RFID and the analysis and aspects of RFID usage in supply chain are given by Dolgui \& Proth (2008). Choi \& Sethi (2010) divide literature about quick response supply chain systems in three main areas (supply information management, demand information management and values of information and supporting technologies) and present current state of knowledge in each area. They emphasize the supporting technologies for values of information. 
The main objective of the supply chain management is integration and coordination of the business activities performed by enterprises associated in the supply chain. The terms 'internal' and 'external' supply chain are widespread in literature, e.g. (Tarn, Yen \& Beaumont, 2002; Pagell, 2004; Meijboom \& Obel, 2007; Huin, Luong \& Abhary, 2002; Bergström \& Stehn, 2005; Forgionne \& Guo, 2009).Thanks to rapid development of information and communication technologies, enterprises realize a more responsive supply chain.

ERP system with RFID system integrates many business processes which enable fast and accurate data access. Also, integration and coordination of supply chain and ERP system is very important in various industries (Tarn, Yen \& Beaumont, 2002; Koh, Saad \& Arunachalam, 2006). The enterprises that coordinate and integrate within a supply chain have better operational efficiency, superior quality of products, lower inventory investments, reduction in the cash flow cycle time, reduced cycle times, lower material acquisition costs, higher employee productivity and increased ability to meet deadlines requested by customers (Kannan \& Tan, 2005).

The supply chain coordination problem in a just-in time environment with use of RFID technology has been treated in literature (R.S. Chen \& Tu, 2009; Huang, Zhang \& Jiang, 2007; Poon et al., 2011a; Gunasekaran, Lai \& Cheng, 2008). Monitoring of the supply chain processes is one of the most important aspects in supply chain management. Primary purpose of supply chain management (SCM) is effectively integrating the information and material flows within the demands and supply processes between suppliers and end customers, including manufacturers, distributors, retailers, and any other enterprises within the extended supply chain, with the special goal of adding value to the customer (Gunsekaran, Lai \& Cheng, 2008, Kannan \& Tan, 2005, Soroor, Tarokh \& Shemshadi, 2009).

Fig. 1 presents market share by revenue of SCM software vendors, the largest share have recognized worldwide SAP with $20 \%$ and Oracle with $17 \%$.

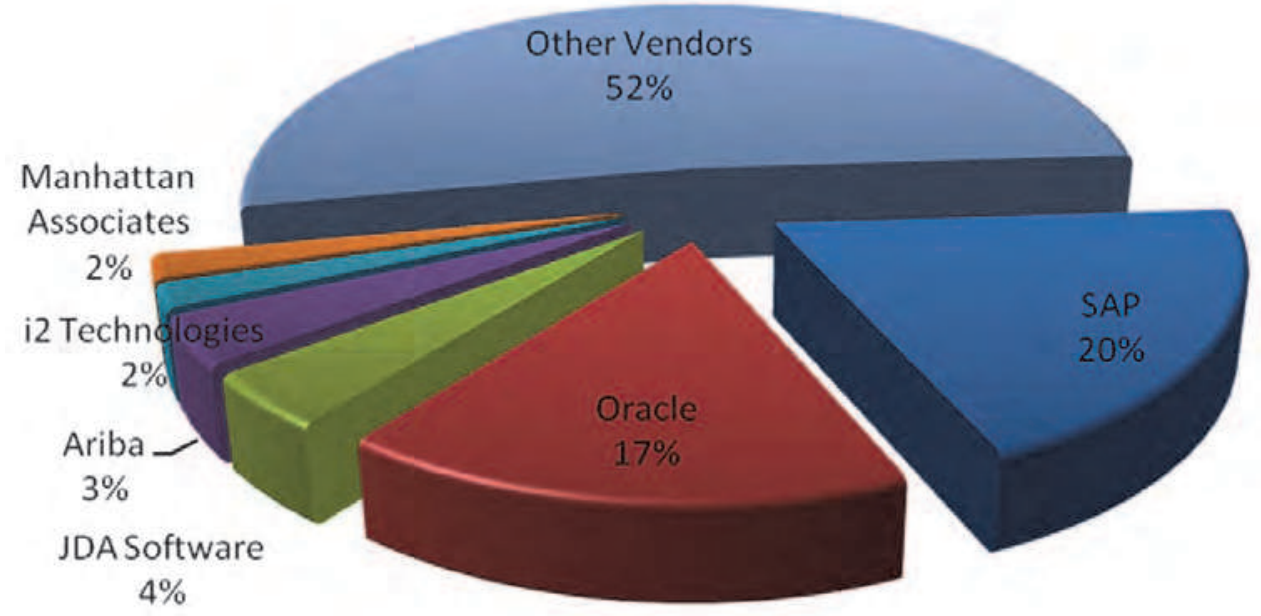

Fig. 1. Worldwide SCM Vendor Software Revenue (Gartner, 2010) 
The prevailing opinion in the literature is that the most successful enterprises are "those that have carefully linked their internal processes to external suppliers and customers in unique supply chains" (Mitra \& Singhal, 2008, as cited in Frohlich \& Westbrook, 2001).

\section{Overview of RFID technology}

Application areas of RFID technology will spread more and more. RFID information about product enables visibility in supply chain by sharing information between supply chain partners. Enterprises must continuously improve the quality of their supply chains with aims to enable visibility of supply chains and reduce operational costs of supply chains. Literature survey presented by Ngai et al. (2008) shows that about a third (36\%) of all RFID research is focused on RFID technology and components of RFID system.

\subsection{RFID system}

A simple RFID system includes three main components: tag, reader and computer or enterprise system (Fig. 2). Tag is composed of a small microchip and an antenna and can be embedded into or attached to objects of any kind (e.g. parts, products, tools, animals, persons). Tags have different shapes and sizes and have a memory for data storage. These are specific data such as a unique identification number, product price, product location, date of manufacturing, current inventory, type, description, dimensions and so on.

There are two basic types of tag:

- passive (without internal batteries),

- $\quad$ active (with battery, self-powered).

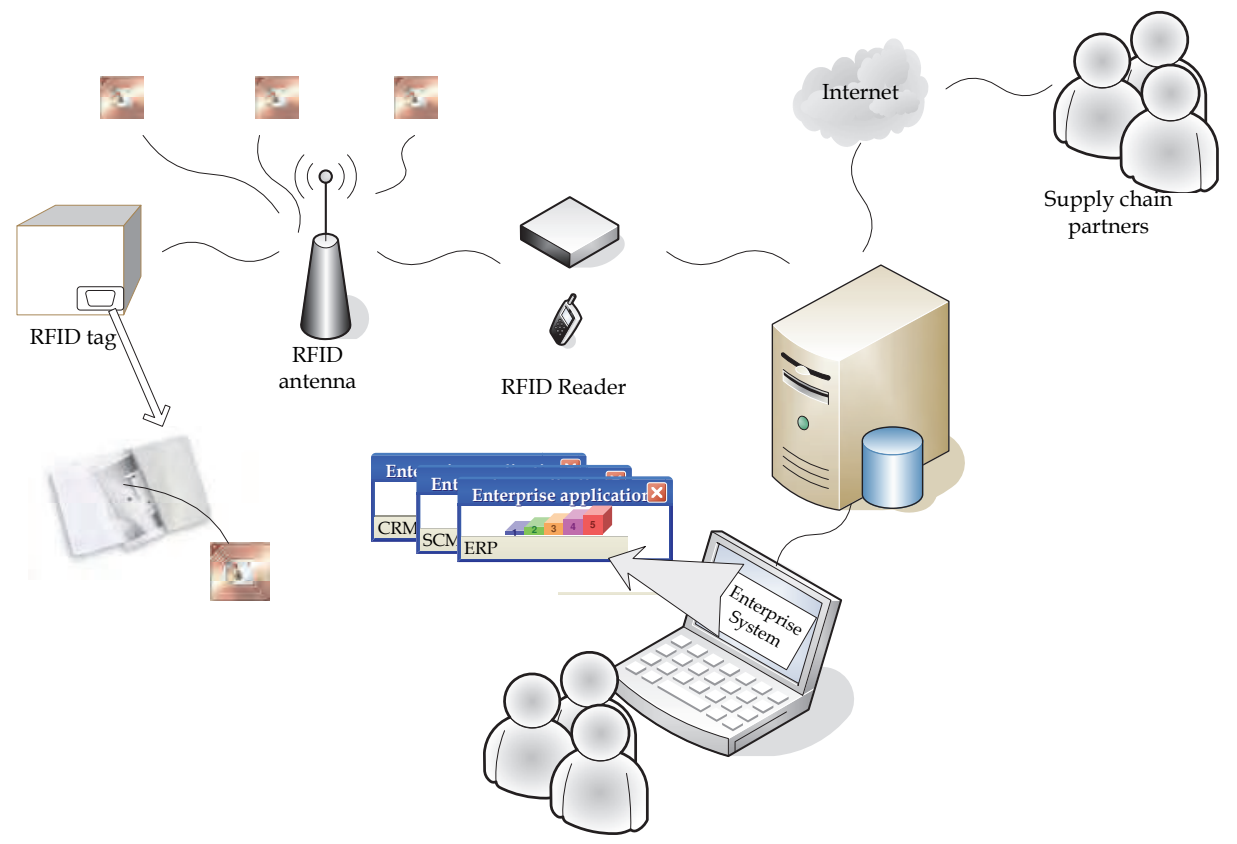

Fig. 2. Components of RFID system 
Active tags have feature of read and write data and larger data storage than passive tags. Also, active tags are self-powered and do not depend on the electromagnetic field of the reader in order to be activated. Active tags use their own batteries as a power source that is integrated on the tag, as opposed to passive tags that receive power from the reader when they are within range of reader. Activation of passive tag depends on the electromagnetic field that is induced by the RFID reader. RFID reader transmits radio signals through antenna in order to activate tag and the identification and recording of data. When tag is activated then data transfers according to signals sent from the antenna. Passive tags are much more used in various RFID applications and duration of passive tags is longer than the active tags, but active tags can transmit signals over a longer distance than passive tags. The most common choice of tag for supply chain usage is passive tags that take effect in the UHF frequency range (Tajima, 2007).

Tags also differ by their data storage capability (Domdouzis, Kumar \& Anumba, 2007):

- Read-Only tags,

- $\quad$ Read/Write tags.

Differences between active and passive RFID tags are summarized in Table 1.

\begin{tabular}{|c|c|c|}
\hline & Active RFID tags & Passive RFID tags \\
\hline Tag power source & Internal to tag & $\begin{array}{l}\text { Energy transferred from the } \\
\text { reader }\end{array}$ \\
\hline Availability of tag power & Continuous & $\begin{array}{c}\text { Only when found in the range } \\
\text { of the reader }\end{array}$ \\
\hline $\begin{array}{l}\text { Required signal strength from } \\
\text { reader to tag }\end{array}$ & Low & High \\
\hline $\begin{array}{c}\text { Available signal strength } \\
\text { from } \\
\text { tag to reader }\end{array}$ & High & Low \\
\hline Communication range & Long range & Short range \\
\hline Multi-tag collection & $\begin{array}{l}\text { Scanning of thousand of } \\
\text { tags } \\
\text { from a single reader } \\
\text { Scanning of up to } 20 \text { tags } \\
\text { moving at more than } 100 \\
\text { miles/hour }\end{array}$ & $\begin{array}{l}\text { Scanning of a hundred of tags } \\
\text { within } 3 \text { meters from a single } \\
\text { reader } \\
\text { Scanning of } 20 \text { tags moving at } \\
3 \text { miles/hour or slower }\end{array}$ \\
\hline Sensor capability & $\begin{array}{l}\text { Ability to monitor } \\
\text { continuously } \\
\text { monitor sensor input }\end{array}$ & $\begin{array}{l}\text { Monitor sensor input when tag } \\
\text { is powered from the reader }\end{array}$ \\
\hline Data Storage & Large & Small \\
\hline
\end{tabular}

Table 1. Differences between active and passive RFID tags (Domdouzis, Kumar \& Anumba, 2007)

RFID reader communicates wirelessly with RFID tag that attached to a product when the product is located within range of the reader. RFID reader reads the information stored in the memory of tags and transfers them to a computer or enterprise application. This information can quickly be read by a wireless communication among compatible reader and tags in the readers range. 
RFID system has to computerise a large amount of data and improve efficiency of operations. There is need of filtering and processing of large amount of data that captured by RFID system and transforming data into meaningful information in order to be used in enterprise applications, such as enterprise resource planning (ERP), supply chain management (SCM) and/or customer relationship management (CRM). These functions are performed by middleware.

The RFID middleware system between readers and applications is composed of two interfaces, namely the application interface and the reader interface, to communicate with the environment.

\subsection{RFID frequency}

The frequency used for RFID application is an important characteristic of RFID system. There is diversity through regulation by individual country about RFID frequency allocation (Turcu, Turcu \& Graur, 2009). One of the major problems in the application of RFID systems is existence of different standards. The diversity in national spectrum allocation for RFID is an obstacle to wider application of RFID systems in the world and one of the key issues of the RFID technologies is their standardization (D. Lee \& Park, 2010).

Presently only a few frequencies are consistent around the world. There are different operational frequency ranges (Gaukler \& Seifert, 2007; Oztaysi, Baysan \& Akpinar, 2009, Wu et al, 2006):

low frequency (LF) $125-134 \mathrm{kHz}$,

- $\quad$ high frequency $(\mathrm{HF}) 13.56 \mathrm{MHz}$,

- $\quad$ and ultra high frequency (UHF) RFID uses 868-928 MHz.

Higher frequency enables reading at longer distances and also faster communication (Gaukler \& Seifert, 2007). Low-frequency passive tags have an effective range of approximately $30 \mathrm{~cm}$, while high-frequency passive tags are useful in the range about $1 \mathrm{~m}$. Ultra high frequency (UHF) passive tags have range about $8 \mathrm{~m}$ (Meyer, Främling \& Holmström, 2009; Roberts, 2006). Active tags are self-powered and more expensive than passive tags but can reach a range of $100 \mathrm{~m}$ (Wang, Lin \& Lin, 2007).

\subsection{RFID history and trends}

RFID technology is not new technology. One of the first papers about RFID is published in 1948 by Harry Stockman (Roberts, 2006). RFID was developed during 1940's, but the use of technology was limited due to high costs of the RFID tags. Commercial use of RFID starts during 1960's (the electronic article surveillance (EAS) system, animal tagging, toll road payment systems, using RFID in automotive industries for assembly lines), but the application in supply chain management is relatively new (Tajima, 2007). RFID usage has increased in recent years in a wide range of various application and we can expect significant growth of RFID market in the next years. The explanation for the growing interest in RFID can be found in reducing prices of passive tags and development capabilities of internet technology (Roussos \& Kostakos, 2009).

\subsection{Electronic Product Code}

The Electronic Product Code (EPC) is a common way for automatic and unique identification of objects (parts, products, pallets, locations, etc.), i.e. „a standard product coding structure for item management applications" (Poon et al., 2011a). The EPC is 
prevalent method for assigning unique product identification in the modern supply chain environment. The EPC standard is announced by nonprofit organization EPCGlobal Network with aim of facilitate data exchange between supply chain partners through standard interface and without having direct access to the underlying databases (Vrba, Macůrek \& Mařík, 2008).

\subsection{RFID benefits}

Many authors mentioned that RFID contributes to supply chains operations through its unique identification of objects and real-time information, thereby RFID improves the data accuracy, accelerates processes, enables the traceability and the visibility of products throughout supply chains, increases speed of physical flows and reduces of Work- InProgress and inventories (Dolgui \& Proth, 2008).

Use of RFID technology as well as bar codes, facilitates automation of processes and improves operations management through reduction of workload and elimination of human errors.

However, RFID technology has some advantages over the bar code:

- there is no need for line of sight (tags can be read through a different materials),

- suitable for harsh environments (e.g. dirt, moisture, dust, chemicals, high temperatures),

- the RFID reader could interact with multiple tags and automatically receive information from the tags,

- RFID readers greater distances of reading,

- tags contain more data than bar codes,

- form and dimensions of tags could be various, depending on the application.

There are some limitations about RFID application, e.g. physical limitation (difficulties with reading through liquid or metals) and cost of RFID although prices continuously decrease.

\subsection{RFID applications}

Application of RFID technology is possible in wide area of human activity. An increasing variety of enterprises are using RFID to improve their efficiency of operations and to gain a competitive advantage. The innovation in RFID is not in the technology itself, but in its use in real-business processes. The rapid development of information technology and reducing cost of RFID system components enable continuous expansion of application areas. Applications of radio frequency identification (RFID) technology within supply chain management have received particular attention in the past few years by many authors. In literature some of named applications of RFID are: fashion product development (Choy et al., 2009), real-time warehouse operation planning system (Poon et al., 2011a; Chow et al., 2006), solving production material demand problem in manufacturing environment (Poon et al., 2011b; Huang, Zhang \& Jiang, 2007), hospitality (Öztayşi, Baysan, Akpinar, 2009), construction (Wang, 2008; Ergen, Akinci \& Sacks, 2007; Wang, Lin \& Lin, 2007; Yagi, Arai \& Arai, 2005), monitoring quality in a food logistics (Ngai, Suk \& Lo, 2008; Vergara et al.., 2007), tracking vehicles in an automotive manufacturing plant shipment yard (J. Kim et al.., 2010), health care (Oztekin et al.., 2010; Katz \& Rice, 2009), service sector (L.S. Lee, Fiedler \& Smith, 2008), farm management systems (animal identification) (Voulodimos et al., 2010), prevention of collision accidents with heavy equipment (Chae \& Yoshida, 2010), libraries 
(Coyle, 2005), parking management (Jian, Yang \& Lee, 2008), traffic management (Wen, 2010), maintenance (C.H. Ko, 2009; T.L. Chen, 2009), postal services (Zhang, Yue \& Wang, 2006), etc. Wal-Mart, the US Department of Defense, Metro, Marks and Spencer, Benetton and Gillette are some of the first, worldwide known users of RFID technology for their supply chains (Ngai et al., 2008; Wu et al., 2006; Roberts, 2006).

Application of RFID technology is increasing in various industries as prices continuously decrease. According to data from Eurostat, the statistical office of the European Union (Eurostat, 2010) the most common application of RFID technology in enterprises in the EU (in January 2009) was in the area of person identification or access control (56\%), supply chain management and inventory tracking and tracing $(29 \%)$, payment $(25 \%)$, product identification $(24 \%)$, monitoring of industrial production $(21 \%)$ and service and maintenance information management (15\%).

Fig. 3 presents applications of RFID by purpose in enterprises in the EU and Croatia, first quarter 2009 (Eurostat, 2010; Croatian Bureau of Statistics, 2010). RFID was mostly used by Croatian enterprises for person identification and/or access control and for payment applications (e.g. toll collection). Renko \& Ficko (2010) indicate that Croatian retailers do not use new logistics technologies sufficiently; particularly enterprises from studied sample do not use RFID for products labelling. Authors explained that fact with high costs of RFID employment per unit with compare to low costs of labour that retailers employ for product labelling.

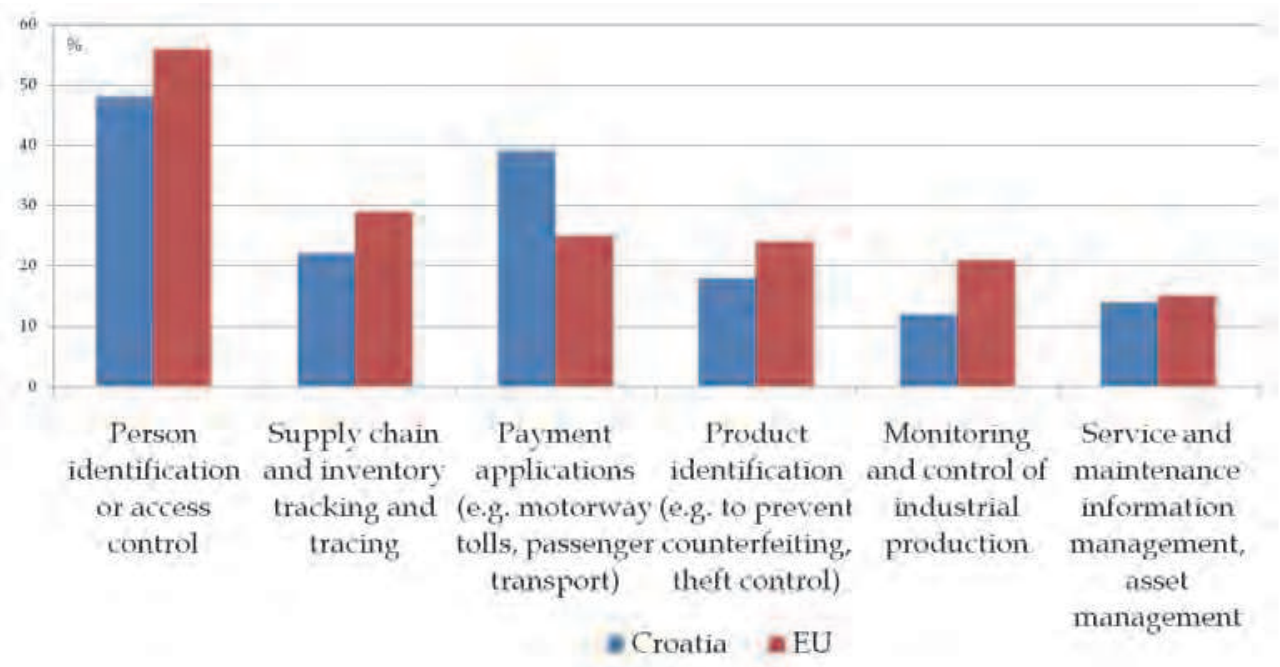

Fig. 3. Applications of RFID usage in enterprises by purpose, first quarter 2009 (Eurostat, 2010)

As seen in Fig. 4 the highest shares of enterprises which used RFID in January 2009, had Netherlands (9\%), Finland (8\%), Germany, Spain, Austria and Slovakia (all 4\%), and the lowest shares had Greece, Cyprus and Romania (all 1\%). At the same period Croatia had $4 \%$ of enterprises using RFID which is slightly higher than average use in the EU27 of $3 \%$. 

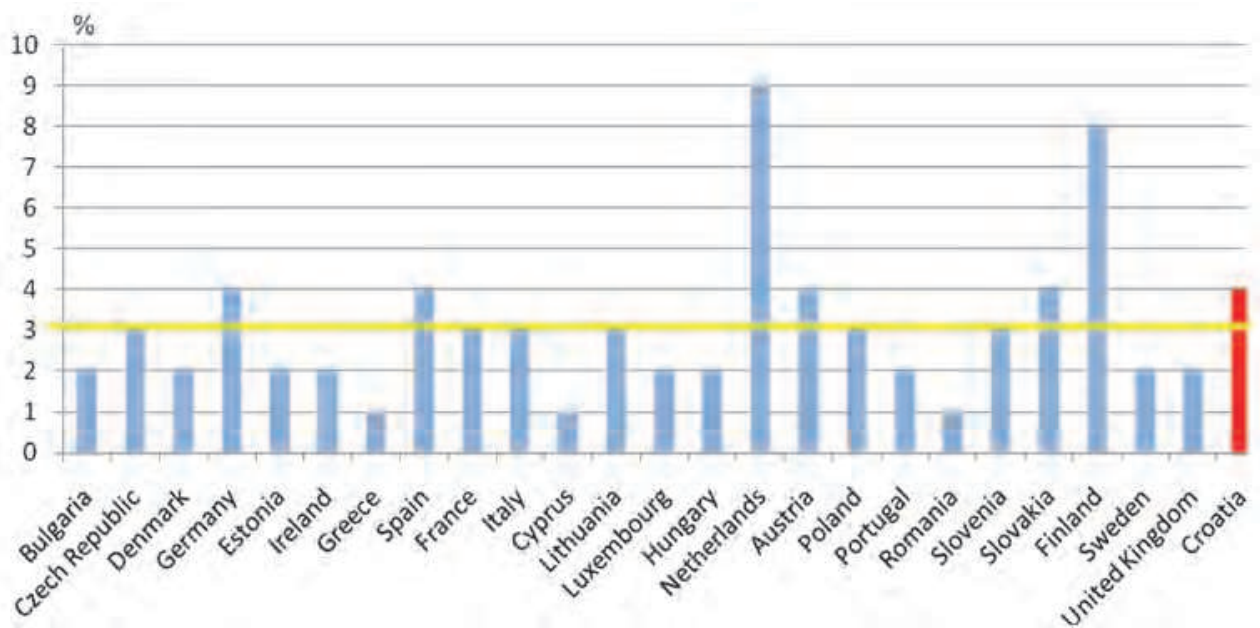

Fig. 4. Enterprises that used RFID in January 2009 (\% of all enterprises) (Eurostat, 2010)

\section{Conceptual framework}

Since RFID technology facilitates collection of data, it is necessary to integrate RFID with ERP system and with various information systems of supply chain partners in order to get a meaningful data. Providing that supply chain operations performed according to plan is a significant continuous activity. With ERP system and RFID any drawback (e.g. material shortages) could be timely identified and corrective action could be taken if necessary. For internal end external supply chain it is very important that the real-time information flow is oriented backwards through the integrated supply chain, as parts, components, products, etc. flow forward according to just-in-time principle. Thereby, it is possible to reduce order delays, lead times and inventory and therefore, increase customer satisfaction.

Our conceptual framework for integration of ERP system and RFID technology with aim of providing information visibility in internal as well as external supply chain is based on justin-time principles (produce and deliver products or services as needed by customer or required by hierarchically superior level in the required quantities, just in time when needed and at right place avoiding storage whenever possible or using minimal inventories). In order to provide a just in time environment, status information of manufactured parts should be available to all who needs that information within enterprise and also between supply chain partners in real time. Conceptual framework for integration RFID with ERP system includes hierarchical planning model that connects level of sales planning, level of assembly planning and level of production scheduling (Matičević, Lovrić \& Čičak, 2007; Matičević, Dabić \& Daim, 2010). Hierarchical planning model generates plans and schedules that are consistent with dynamic business processes. Connection of the three levels of planning in compliance with just-in-time principle enables increase of efficiency, timely delivery of finished products/services to the customer (or parts and subassemblies to a product assembly according to hierarchically superior level of plan). The hierarchically superior levels and subordinate levels of planning are interdependent according just-in time principle. Objective of hierarchical planning model is to keep the due date equal to the 
required date in order to meet customers' demands, thus the solution of a subordinate planning / scheduling level must meet requirements from the superior planning level. RFID tags could be attached on objects (as parts, subassemblies, components, products, containers) allowing us effective tracking of objects in the production process. Fast data acquisition and transfers of data to databases are facilitated by RFID technology. Products with tags have a unique identification number and could store relevant manufacturing information (e.g. material used production status). Collected RFID data have to transform into an appropriate report in order to share information within the enterprise and between partners in the supply chain.

The aim of our conceptual framework (Fig. 5) is to provide visibility of material and information flows, which includes the processes from customer orders through manufacturing and product assembly to delivery of the product to the customer. It refers only to a part of the entire supply chain. Our aim is to facilitate the sharing of information with the integration of RFID technology in the the Croatian solution of ERP system in the digital enterprise, named ERPINS. ERPINS has been designed for metal processing industry, wood and food processing industry and construction industry. For the purposes of developing the conceptual framework we have chosen the local ERP system due to the following reasons:

- local software developers are more familiar with the peculiarities of the market conditions and Croatian law, therefore their ERP solutions are more flexible to legislative changes that often occur in countries in transition such as Croatia;

- local ERP solutions are more competitive due to the lower prices compared with global vendors.

Fig. 5 shows prominent ERPINS screenshot of real-time production status monitoring and data update using RFID Handheld Reader/Writer. Machine worker at shopfloor with the handheld RFID reader can make data entry about quantities of parts processed and this data is available in real-time throughout ERPINS system. This real-time feature of ERPINS is very important for control of deviation in production, as the performance of entire supply chain may be adversely affected by deviation from the production schedule. Integration of RFID and ERP systems enables visibility of information about real-time production status directly from production shop floor (e.g. accurate information about inventory levels, about start time and finish time of operation). This enables dynamic and real-time control of production and adjustment of the production schedule to disturbance in production process. RFID tags are placed on parts to prevent loss of parts and to monitor production status. Using RFID tags, parts and products can be traced through the processes of production and assembly.

Coordination of internal supply chain has been achieved when the parts from the production are transferred to the next stage (product assembly) immediately after the part is completed and it depends on the date required by the hierarchically superior plan (e.g. the level of assembly). Tagging parts, products or containers is useful for each partner in the supply chain due to providing the visibility of material and information flows.

RFID enables real-time access to information and minimizes the time and work needed for collecting information. Real-time automatic identification and data capture system, as RFID system, is highly important for agile production. When integrated with ERP system, RFID provide an online current status of all material inventories and Work-In-Process. 

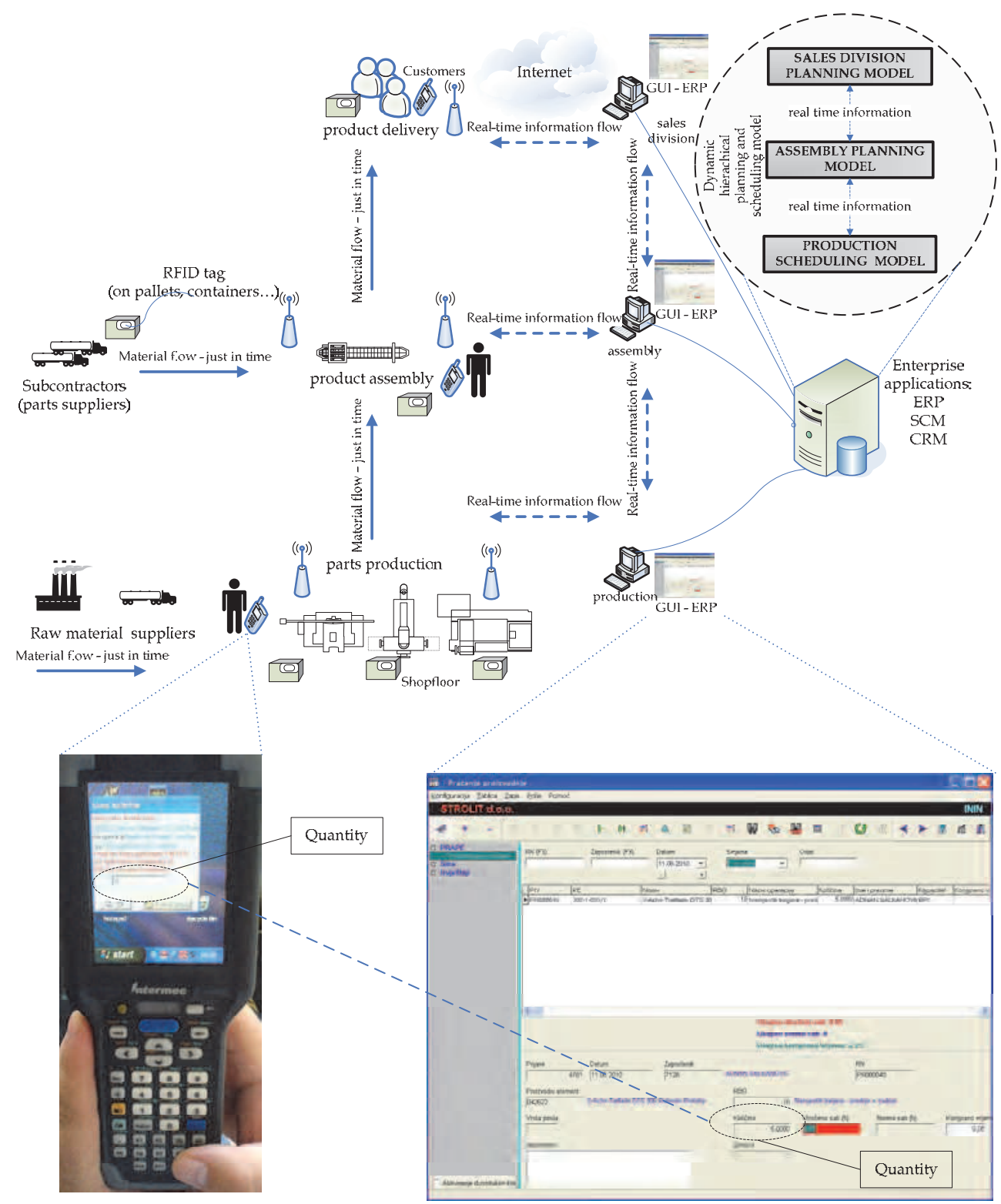

Fig. 5. Conceptual framework of information sharing enabled with RFID and ERP integration, adapted from (Matičević, Dabić \& Daim, 2010) 


\section{Conclusion}

Automatic identification and capture data technology like RFID can be useful in order to improve business efficiency. In terms of management, integration of ERP and RFID allows effective decision-making considering customer requirements and efficient use of enterprise resources.

This chapter is the result of literature review and experience of authors about application of RFID in enterprises and provides an overview of the current state of development of RFID technology and its application in practice. The chapter is useful to researchers, practitioners and other interested parties to apply RFID in manufacturing and supply chain to understand the importance of real-time visibility in supply chain management in order to improve operational performance. RFID based identification and data capture is appropriate for overcoming the problems in production and other business processes, which are caused by manual identification and collecting data. Integration of ERP system and RFID technology can provide real-time tracking work orders, parts and products, data accuracy and information sharing through internal and external supply chain. Limitation of research is that validation of the proposed conceptual framework is required through practical implementation in real manufacturing environment.

Future research should include the development of mathematical model based on the conceptual framework described in this chapter.

\section{Acknowledgment}

The results presented in this chapter are derived from the research project "MANAGERIAL TOOLS IN DIGITAL ENTERPRISE" (Code No. 067-0000000-3351) supported by the Ministry of Science, Education and Sports of the Republic of Croatia.

\section{References}

Angeles, R. (2009). Anticipated IT infrastructure and supply chain integration capabilities for RFID and their associated deployment outcomes. International Journal of Information Management, Vol. 29, No. 3, June 2009, pp. 219-231, ISSN: 0268-4012

Attaran, M. (2007). RFID: an enabler of supply chain operations. Supply Chain Management: An International Journal, Vol. 12, No. 4, pp. 249-257, ISSN: 1359-8546

Bergström, M. \& Stehn, L. (2005). Matching industrialised timber frame housing needs and enterprise resource planning: A change process. International Journal of Production Economics, Vol. 97, No. 2, August 2005, pp. 172-184, ISSN: 0925-5273

Chae, S. \& Yoshida, T. (2010). Application of RFID technology to prevention of collision accident with heavy equipment. Automation in Construction, Vol. 19, No. 3, May 2010, pp. 368-374, ISSN: 0926-5805

Chang, S.; Klabjan, D. \& Vossen, T. (2010). Optimal radio frequency identification deployment in a supply chain network. International Journal of Production Economics, Vol. 125, No. 1, May 2010, pp. 71-83, ISSN: 0925-5273 
Chao, C.C.; Yang, J.M. \& Jen, W.Y. (2007). Determining technology trends and forecasts of RFID by a historical review and bibliometric analysis from 1991 to 2005. Technovation, Vol. 27, No. 5, May 2007, pp. 268-279, ISSN: 0166-4972

Chatziantoniou, D., Pramatari, K. \& Sotiropoulos, Y. (2011). Supporting real-time supply chain decisions based on RFID data streams. Journal of Systems and Software, Vol. 84, No. 4, April 2011, pp. 700-710, ISSN: 0164-1212, doi:10.1016/ j.jss.2010.12.011

Chen, R.S. \& Tu, M.A. (2009). Development of an agent-based system for manufacturing control and coordination with ontology and RFID technology. Expert Systems with Applications, Vol. 36, No. 4, May 2009, pp. 7581-7593, ISSN: 0957-4174

Chen, T.L. (2009). Real-time turbine maintenance system. Expert Systems with Applications, Vol. 36, No. 4, May 2009, pp. 8676-8681, ISSN: 0957-4174

Choi, T.M. \& Sethi, S. (2010). Innovative quick response programs: A review. International Journal of Production Economics, Vol. 127, No. 1, September 2010, pp. 1-12, ISSN: 0925-5273

Chow, H.K.H.; Choy, K.L.; Lee, W.B. \& Lau, K.C. (2006). Design of a RFID case-based resource management system for warehouse operations. Expert Systems with Applications, Vol. 30, No. 4, May 2006, pp. 561-576, ISSN: 0957-4174

Choy K.L.; Chow, K.H.; Moon, K.L.; Zeng, X.; Lau, H.C.W.; Chan, F.T.S.; Ho, G.T.S. (2009). A RFID-case-based sample management system for fashion product development. Engineering Applications of Artificial Intelligence, Vol. 22, No. 6, September 2009, pp. 882-896, ISSN: 0952-1976

Coyle, K. (2005). Management of RFID in Libraries. The Journal of Academic Librarianship, Vol. 31, No. 5, September 2005, pp. 486-489, ISSN: 0099-1333

Croatian Bureau of Statistics. (28 January 2010). Usage of Information and Communication Technologies (ICT) in enterprises, 2009, First Results, In: First Release, 13 June 2010, Available from: http://www.dzs.hr/Eng/Publication/2009/2-1-8_1e2009.htm

Dias, J.C.Q.; Calado, J.M.F.; Osório, A.L. \& Morgado, L.F. (2009). RFID together with multiagent systems to control global value chains. Annual Reviews in Control, Vol. 33, No. 2, December 2009, pp. 185-195, ISSN: 1367-5788

Dolgui, A. \& Proth, J.M. (2008). RFID Technology in Supply Chain Management: State of the Art and Perspectives. Proceedings of the 17th IFAC World Congress, ISSN 1474-6670, Seoul, Korea, July 6-11, 2008, pp. 4464-4475

Domdouzis, K.; Kumar, B. \& Anumba, C. (2007). Radio-Frequency Identification (RFID) applications: A brief introduction. Advanced Engineering Informatics, Vol. 21, No. 4, October 2007, pp. 350-355, ISSN: 1474-0346

Ergen E.; Akinci B. \& Sacks, R. (2007). Life-cycle data management of engineered to-order components using radio frequency identification. Advanced Engineering Informatics, Vol. 21, No. 4, October 2007, pp. 356-366, ISSN: 1474-0346

Eurostat Press Office. (19 January 2010). E-commerce accounted for 12\% of enterprises' turnover in the EU27 in 2008, In: Eurostat Newsrelease, June 2010, Available from: http://epp.eurostat.ec.europa.eu/cache/ITY_PUBLIC/4-19012010-BP/EN/419012010-BP-EN.PDF 
Forgionne, G. \& Guo, Z. (2009). Internal supply chain coordination in the electric utility industry. European Journal of Operational Research, Vol. 196, No. 2, July 2009, pp. 619-627, ISSN: 0377-2217

Gartner, Inc. 2010. (16 June 2010). Gartner Says Worldwide Supply Chain Management Software Market Contracted by 0.7 Percent in 2009, In: Gartner Newsroom, Press Releases, 26 January 2011, Available from:

http://www.gartner.com/it/page.jsp?id=1388214

Gaukler, G. \& Seifert, R. (2007). Applications of RFID in Supply Chains, In: Trends in Supply Chain Design and Management, Springer Series in Advanced Manufacturing, Part I., Eds: Jung, H., Chen, F.F. \& Jeong, B., pp. 29-48, Springer-Verlag Ltd. London, ISBN: 9781-84628-606-3, London

Gunasekaran, A.; Lai, K.H. \& Cheng, T.C.E. (2008). Responsive supply chain: A competitive strategy in a networked economy. Omega, Vol. 36, No. 4, August 2008, pp. 549-564, ISSN: 0305-0483

Huang, G.; Zhang, Y.F. \& Jiang, P.Y. (2007). RFID-based wireless manufacturing for walking-worker assembly islands with fixed-position layouts. Robotics and Computer-Integrated Manufacturing, Vol. 23, No. 4, August 2007, pp. 469-477, ISSN: 0736-5845

Huin, S.F.; Luong, L.H.S. \& Abhary, K. (2002). Internal supply chain planning determinants in small and medium-sized manufacturers. International Journal of Physical Distribution \& Logistics Management, Vol. 32, No. 9, pp. 771-782, ISSN: 0960-0035

Jian, M.S.; Yang, K.S. \& Lee, C.L. (2008). Modular RFID Parking Management System based on Existed Gate System Integration. WSEAS Transactions on System, Vol. 7, No. 6, June 2008, pp. 706-716, ISSN: 1109-2777

Kannan, V. R. \& Tan, K. C. (2005). Just in time, total quality management, and supply chain management: understanding their linkages and impact on business performance. Omega, Vol. 33, No. 2, April 2005, pp. 153-162, ISSN: 0305-0483

Katz, J.E. \& Rice, R.E. (2009). Public views of mobile medical devices and services: A US national survey of consumer sentiments towards RFID healthcare technology. International Journal of Medical Informatics, Vol. 78, No. 2, February 2009, pp. 104-114, ISSN: $1386-5056$

Kim, E.Y.; Ko, E.; Kim, H.J. \& Koh, C.E. (2008). Comparison of benefits of radio frequency identification: Implications for business strategic performance in the U.S. and Korean retailers. Industrial Marketing Management, Vol. 37, No. 7, October 2008, pp. 797-806, ISSN: 0019-8501

Kim, J.; Ok, C.S.; Kumara, S.; Yee, S.T. (2010). A market-based approach for dynamic vehicle deployment planning using radio frequency identification (RFID) information. International Journal of Production Economics, Vol. 128, No. 1, November 2010, pp. 235-247, ISSN: 0925-5273

Ko, C.H. (2009). RFID-based building maintenance system. Automation in Construction, Vol.18, No. 3, May 2009, pp. 275-284, ISSN: 0926-5805 
Ko, J.M.; Kwak, C.; Cho, Y. \& Kim, C.O. (2011). Adaptive product tracking in RFID-enabled large-scale supply chain. Expert Systems with Applications, Vol. 38, No. 3, March 2011, pp. 1583-1590, ISSN: 0957-4174, doi:10.1016/j.eswa.2010.07.077

Koh, S.C. L.; Saad, S. \& Arunachalam, S. (2006). Competing in the 21st century supply chain through supply chain management and enterprise resource planning integration. International Journal of Physical Distribution \& Logistics Management, Vol. 36, No. 6, pp. 455-465, ISSN: 0960-0035

Lee, D. \& Park, J. (2010). RFID-enabled Supply Chain Traceability: Existing Methods, Applications and Challenges, Sustainable Radio Frequency Identification Solutions, Cristina Turcu (Ed.), ISBN: 978-953-7619-74-9, InTech, (February 2011), Available from:http://www.intechopen.com/articles/show/title/rfid-enabled-supplychaintraceability-existing-methods-applications-and-challenges

Lee, L.S.; Fiedler, K.D. \& Smith, J.S. (2008). Radio frequency identification (RFID) implementation in the service sector: A customer-facing diffusion model. International Journal of Production Economics, Vol. 112, No. 2, April 2008, pp. 587-600, ISSN: 0925-5273

Lin, L.C. (2009). An integrated framework for the development of radio frequency identification technology in the logistics and supply chain management. Computers \& Industrial Engineering, Vol. 57, No. 3, October 2009, pp. 832-842, ISSN: 0360-8352

Matičević, G.; Lovrić, T. \& Čičak M. (2007). Using ERP system to improve internal supply chain coordination. Tehnički vjesnik (Technical Gazette), Vol. 14, No. 3-4, December 2007, pp. 11-21, ISSN: 1330-3651

Matičević, G.; Dabić M. \& Daim U.T. (2010). Using RFID for Real-Time Production Management in the Digital Enterprise. Proceedings of 14th International Research / Expert Conference "Trends in the Development of Machinery and Associated Technology" TMT 2010, ISSN: 1840-4944, Mediterranean Cruise, September 2010, pp. 213-216

Meijboom, B. \&, Obel, B. (2007). Tactical coordination in a multi-location and multi-stage operations structure: A model and a pharmaceutical company case. Omega, Vol. 35, No. 3, June 2007, pp. 258-273, ISSN: 0305-0483

Meyer, G.G.; Främling, K. \& Holmström, J. (2009). Intelligent Products: A survey. Computers in Industry, Vol. 60, No. 3, April 2009, pp. 137-148, ISSN: 01663615

Mitra, S. \& Singhal, V. (2008). Supply chain integration and shareholder value: Evidence from consortium based industry exchanges. Journal of Operations Management, Vol. 26, No. 1, January 2008, pp. 96-114, ISSN: 0272-6963

Ngai, E.W.T.; Suk, F.F.C. \& Lo, S.Y.Y. (2008). Development of an RFID-based sushi management system: The case of a conveyor-belt sushi restaurant. International Journal of Production Economics, Vol. 112, No. 2, April 2008, pp. 630-645, ISSN: 09255273

Oztekin, A.; Pajouh, F.M.; Delen, D. \& Swim, L.K. (2010). An RFID network design methodology for asset tracking in healthcare. Decision Support Systems, Vol. 49, No. 1, April 2010, pp. 100-109, ISSN: 0167-9236 
Öztayşi, B.; Baysan, S. \& Akpinar, F. (2009). Radio frequency identification (RFID) in hospitality. Technovation, Vol. 29, No. 9, September 2009, pp. 618-624, ISSN: 01664972

Pagell, M. (2004). Understanding the factors that enable and inhibit the integration of operations, purchasing and logistics. Journal of Operations Management, Vol. 22, No. 5, October 2004, pp. 459-487, ISSN: 0272-6963

Poon, T.C.; Choy, K.L.; Chow H.K.H.; Lau H.C.W.; Chan F.T.S. \& Ho, K.C. (2009). A RFID case-based logistics resource management system for managing order picking operations in warehouses. Expert Systems with Applications, Vol. 36, No. 4, May 2009, pp. 8277-8301, ISSN: 0957-4174

Poon, T.C.; Choy, K.L.; Chan, F.T.S.; Ho, G.T.S.; Gunasekaran, A.; Lau, H.C.W. \& Chow, H.K.H. (2011a). A real-time warehouse operations planning system for small batch replenishment problems in production environment. Expert Systems with Applications, Vol. 38, No. 7, July 2011, pp. 8524-8537, ISSN: 0957-4174

Poon, T.C.; Choy, K.L.; Chan, F.T.S. \& Lau, H.C.W. (2011b). A real-time production operations decision support system for solving stochastic production material demand problems. Expert Systems with Applications, Vol. 38, No. 5, May 2011, pp. 4829-4838, ISSN: 0957-4174

Renko, S. \& Ficko, D. (2010). New logistics technologies in improving customer value in retailing service. Journal of Retailing and Consumer Services, Vol. 17, No. 3, May 2010, pp. 216-223, ISSN: 0969-6989

Roberts, C.M. (2006). Radio frequency identification (RFID). Computers \& Security, Vol. 25, No. 1, February 2006, pp. 18-26, ISSN: 0167-4048

Roussos, G. \& Kostakos, V. (2009). RFID in pervasive computing: State-of-the-art and outlook. Pervasive and Mobile Computing, Vol. 5, No. 1, February 2009, pp. 110-131, ISSN: $1574-1192$

Sarac, A., Absi, N. \& Dauzere-Peres, S. (2008). A simulation approach to evaluate the impact of introducing RFID technologies in a three-level supply chain. Proceedings of the 40th Conference on Winter Simulation 2008, ISBN: 978-1-4244-2708-6, Miami, FL, USA, December 2008, pp. 2741-2749

Sarac, A.; Absi, N. \& Dauzère-Pérès, S. (2010). A literature review on the impact of RFID technologies on supply chain management. International Journal of Production Economics, Vol. 128, No. 1, November 2010, pp. 77-95, ISSN: 0925-5273

Sari, K. (2010).Exploring the impacts of radio frequency identification (RFID) technology on supply chain performance. European Journal of Operational Research, Vol. 207, No. 1, November 2010, pp. 174-183, ISSN: 0377-2217

Soroor, J.; Tarokh, M.J. \& Shemshadi, A. (2009). Initiating a state of the art system for realtime supply chain coordination. European Journal of Operational Research, Vol. 196, No. 2, 16 July 2009, pp. 635-650, ISSN: 0377-2217

Tajima, M. (2007). Strategic value of RFID in supply chain management. Journal of Purchasing and Supply Management, Vol. 13, No. 4, December 2007, pp. 261-273, ISSN: 1478-4092 
Tarn, J. M.; Yen, D. C. \& Beaumont, M. (2002). Exploring the rationales for ERP and SCM integration. Industrial Management \& Data Systems. Vol. 102, No. 1, pp. 26-34. ISSN 0263-5577

Turcu, Co.; Turcu, C. \& Graur, A. (2009). Improvement of Supply Chain Performances Using RFID Technology, Supply Chain the Way to Flat Organisation, Yanfang Huo and Fu Jia (Ed.), ISBN: 978-953-7619-35-0, InTech, Available from: http://www.intechopen.com/articles/show/title/improvement_of_supply_chain _performances_using_rfid_technology

Vergara, A.; Llobet, E.; Ramírez, J.L.; Ivanov, P.; Fonseca, L.; Zampolli, S.; Scorzoni, A.; Becker, T.; Marco, S. \& Wöllenstein, J. (2007). An RFID reader with onboard sensing capability for monitoring fruit quality. Sensors and Actuators B: Chemical, Vol. 127, No. 1, October 2007, pp. 143-149, ISSN: 0925-4005

Voulodimos, A.S.; Patrikakis, C.Z.; Sideridis, A.B.; Ntafis, V.A. \& Xylouri, E.M. (2010). A complete farm management system based on animal identification using RFID technology. Computers and Electronics in Agriculture, Vol. 70, No. 2, March 2010, pp 380-388, ISSN: 0168-1699

Vrba, P.; Macůrek F. \& Mařík, V. (2008). Using radio frequency identification in agentbased control systems for industrial applications. Engineering Applications of Artificial Intelligence, Vol. 21, No. 3, April 2008, pp. 331-342, ISSN: 0952-1976

Wang, L.C.; Lin, Y.C. \& Lin, P.H. (2007). Dynamic mobile RFID-based supply chain control and management system in construction. Advanced Engineering Informatics, Vol. 21, No. 4, October 2007, pp. 377-390, ISSN: 1474-0346

Wang, L.C. (2008). Enhancing construction quality inspection and management using RFID technology. Automation in Construction, Vol. 17, No. 4, May 2008, pp. 467-479, ISSN: 0926-5805

Wen, W. (2010). An intelligent traffic management expert system with RFID technology. Expert Systems with Applications, Vol. 37, No. 4, April 2010, pp. 3024-3035, ISSN: 0957-4174

Wu, N.C.; Nystrom, M.A.; Lin, T.R. \& Yu, H.C. (2006). Challenges to global RFID adoption. Technovation, Vol. 26, No. 12, December 2006, pp. 1317-1323, ISSN: 0166-4972

Yagi, J.; Arai, E. \& Arai, T. (2005). Parts and packets unification radio frequency identification (RFID) application for construction. Automation in Construction, Vol. 14, No. 4, August 2005, pp. 477-490, ISSN: 0926-5805

Yin, X.F., Khoo, L.P. (2007). A hierarchical model for e-supply chain coordination and optimisation. Journal of Manufacturing Technology Management, 2007, Vol. 18, No. 1, pp. 7-24, ISSN: 1741-038x

Zhang, D. (2006). A network economic model for supply chain versus supply chain competition. Omega. Vol. 34, No. 3, June 2006, pp. 283-295, ISSN: 0305-0483

Zhang, X.D.; Yue, S.J. \& Wang, W.M. (2006). The review of RFID applications in global postal and courier services. The Journal of China Universities of Posts and Telecommunications, Vol. 13, No. 4, December 2006, pp. 106-110, ISSN: 10058885 
Zhou, W. (2009). RFID and item-level information visibility. European Journal of Operational Research, Vol. 198, No. 1, October 2009, pp. 252-258, ISSN: 0377-2217 


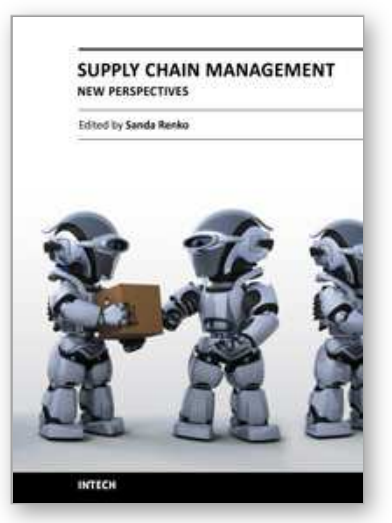

\author{
Supply Chain Management - New Perspectives \\ Edited by Prof. Sanda Renko
}

ISBN 978-953-307-633-1

Hard cover, 770 pages

Publisher InTech

Published online 29, August, 2011

Published in print edition August, 2011

Over the past few decades the rapid spread of information and knowledge, the increasing expectations of customers and stakeholders, intensified competition, and searching for superior performance and low costs at the same time have made supply chain a critical management area. Since supply chain is the network of organizations that are involved in moving materials, documents and information through on their journey from initial suppliers to final customers, it encompasses a number of key flows: physical flow of materials, flows of information, and tangible and intangible resources which enable supply chain members to operate effectively. This book gives an up-to-date view of supply chain, emphasizing current trends and developments in the area of supply chain management.

\title{
How to reference
}

In order to correctly reference this scholarly work, feel free to copy and paste the following:

Gordana Matičević, Mirjana Cičak and Tadija Lovrić (2011). RFID and Supply Chain Management for Manufacturing Digital Enterprise, Supply Chain Management - New Perspectives, Prof. Sanda Renko (Ed.), ISBN: 978-953-307-633-1, InTech, Available from: http://www.intechopen.com/books/supply-chainmanagement-new-perspectives/rfid-and-supply-chain-management-for-manufacturing-digital-enterprise

\section{INTECH}

open science | open minds

\section{InTech Europe}

University Campus STeP Ri

Slavka Krautzeka 83/A

51000 Rijeka, Croatia

Phone: +385 (51) 770447

Fax: +385 (51) 686166

www.intechopen.com

\section{InTech China}

Unit 405, Office Block, Hotel Equatorial Shanghai

No.65, Yan An Road (West), Shanghai, 200040, China

中国上海市延安西路65号上海国际贵都大饭店办公楼 405 单元

Phone: +86-21-62489820

Fax: +86-21-62489821 
(C) 2011 The Author(s). Licensee IntechOpen. This chapter is distributed under the terms of the Creative Commons Attribution-NonCommercialShareAlike-3.0 License, which permits use, distribution and reproduction for non-commercial purposes, provided the original is properly cited and derivative works building on this content are distributed under the same license. 